\title{
Cutaneous leukocytoclastic vasculitis in the presence of methimazole therapy*
}

\section{Vasculite leucocitoclástica cutânea na vigência de terapêutica com metimazol}

\author{
Carla de Oliveira Ribeiro ${ }^{1}$ \\ Enoí Aparecida Guedes Vilar ${ }^{2}$ \\ Rogério Ribeiro Estrella ${ }^{3}$
}

\author{
Paula Ferrazzi Magrin ${ }^{1}$ \\ Sandra Maria Barbosa Durães ${ }^{3}$
}

\begin{abstract}
Treatment with antithyroid drugs may be accompanied by side effects. We present a patient diagnosed with Grave's Disease who developed extensive vasculitis in the lower limbs during methimazole use. After suspension of the methimazole and the introduction of prednisone in immunesupressor doses the cutaneous lesions started to involute.

Keywords: Anti-neutrophil cytoplasmic antibody-associated vasculitis; Methimazole; Vasculitis; Cutaneous leukocytoclastic vasculitis

Resumo: A terapêutica com drogas antitireoidianas pode ser acompanhada de efeitos colaterais. Apresentamos um caso de paciente com diagnóstico de Doença de Graves que na vigência da terapêutica com metimazol desenvolveu um quadro extenso de vasculite de membros inferiores. A partir da suspensão do metimazol e da introdução de prednisona em doses imunossupressoras as lesões cutâneas entraram em involução.

Palavras-chave: Metimazol; Vasculite; Vasculite associada a anticorpo anticitoplasma de neutrófilos; Vasculite leucocitoclástica cutânea
\end{abstract}

\section{INTRODUCTION}

The common therapy for Graves'Disease (GD) prescribes antithyroid drugs (ATD) such as propilthiouracil (PTU) and methimazole (MTM). This therapy may cause a number of side effects such as elevated liver enzymes, leukopenia, skin rash and arthralgia. ${ }^{1-6}$

Vasculitis diseases directly related to the use of ATD are considered to be a group of systemic sicknesses with multiple cutaneous manifestations from erythema to necrosis and histopathological features such as leukocytoclastic vasculitis with fibrinoid necrosis of the vessel walls, in addition to neutrophils in the inflammatory infiltrate. ${ }^{5,7}$
Although the association between Vasculitis and MTM has been previously described its frequency appears to be low when compared to the number of cases involving treatment with PTU. ${ }^{4-6,8,9}$

\section{CASE REPORT}

Female patient, 33-years-old, black, host to GD for over 6 years, using MTM since the onset of symptoms. Patient was advised to seek dermatology assistance due to the emergence of superficial skin lesions in the lower limbs over a period of 20 days, associated with fever, joint pain and tremor of the extremities.

Received on 09.01.2012.

Approved by the Advisory Board and accepted for publication on 22.02.2012.

* Study conducted in the Dermatology Department of the Antônio Pedro University Hospital - Universidade Federal Fluminense (HUAP-UFF) - Niterói (RJ), Brazil. Conflict of interest: None

Financial funding: None

Postgraduate student in the Dermatology Department of the Antônio Pedro University Hospital - Universidade Federal Fluminense (HUAP-UFF) - Niterói (RJ), Brazil.

PhD - Associate Professor in the Pathology Department of the Antônio Pedro University Hospital - Universidade Federal Fluminense (HUAP-UFF) - Niterói (RJ), Brazil.

PhD - Associate Professor of the Dermatology Department of the Antônio Pedro University Hospital - Universidade Federal Fluminense (HUAP-UFF) - Niterói (RJ), Brazil. 
The dermatological exam exposed erythematous purpuric lesions on the dorsum of the feet and plantar cavus tense blisters with hemorrhagic content in the malleolar region which spread to large necrotic areas. (Figures 1,2 and 3).

The chest x-ray and renal function tests failed to detect significant changes. The absence of hematuria was also noted. Laboratory data is presented in table 1

A biopsy of the superficial skin lesion was in addition performed in the right lateral malleolus region. Histopathological examination revealed neutrophilic leukocytoclastic vasculitis of small vessels (Figure 4).

In view of the tests feedback, we decided to discontinue MTM and start therapy with prednisone

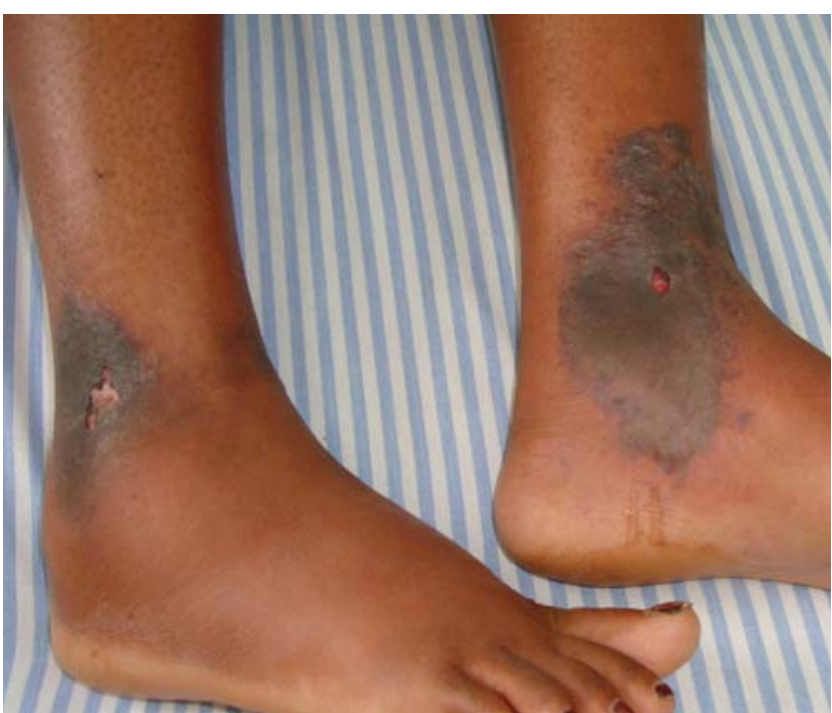

FIGURE 1: Erythematous purpuric lesions and blisters

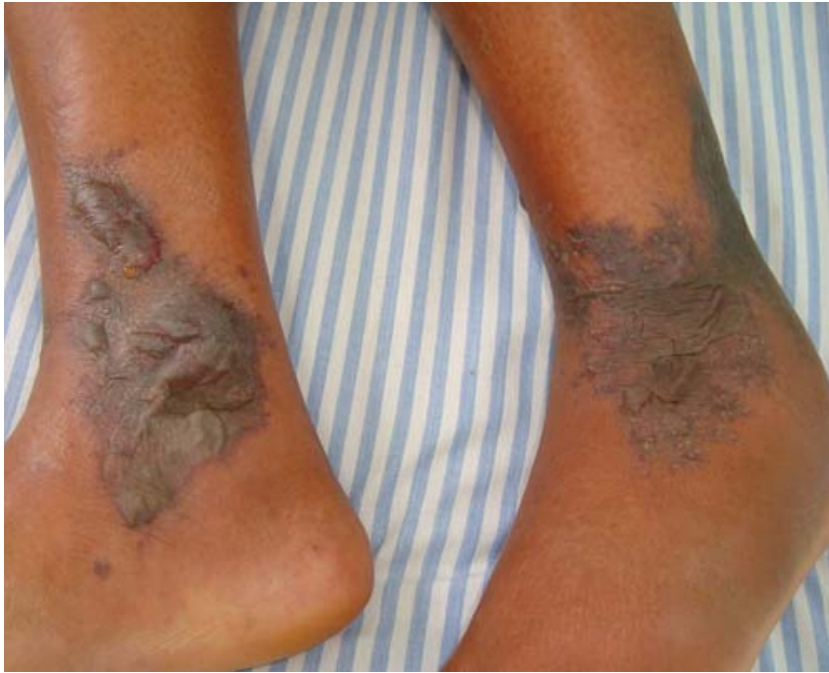

FIGURE 2: Purpuric lesions and blisters with hemorrhagic material
$(1 \mathrm{mg} / \mathrm{kg})$. We were able to observe continuous improvement after 7 days (Figure 5).

\section{DISCUSSION}

ATD drugs can cause a number of systemic changes such as fever, rash, hives, arthralgia/arthritis, sensorineural hearing loss, central nervous system vasculitis, respiratory symptoms (from epistaxis to diffuse alveolar hemorrhage), scleritis, glomerulonephritis, lupus-like syndrome, polychondritis, toxic hepatitis and agranulocytosis. Adverse reactions occur in $1 \%-5 \%$ of patients using these drugs, often with higher doses of MTM, while the use of PTU does not influence the onset of the above-mentioned reactions. ${ }^{1-4,6,7,9}$

In a review of the literature by Cooper certain minor side effects were listed, including dermatological, arthralgia and gastrointestinal tract changes which occurred in approximately $5 \%$ of patients using these drugs, often the same for both. The same author considered the following to be the most prominent side effects: arthritis, positive vasculitis with anti-neutrophil cytoplasmic antibodies (ANCA), agranulocytosis, autoimmune hepatitis, cholestasis, hypoglycemia, pancreatitis and hypoprothrombinemia. ${ }^{1-2}$

Agranulocytosis is the worst side effect, occurring in $0.37 \%$ of the patients using PTU (OCT) and $0.35 \%$ of patients treated with MTM. According to estimates hepatotoxicity can also occur at a frequency of $0.1-0.2 \%{ }^{1-2}$

Vasculitis is the third main toxic reaction observed with the use of DAT, classically associated to PTU therapy. ${ }^{1-2}$ In $30 \%$ of cases of vasculitis triggered by these drugs skin disorders are observed. ${ }^{5}$ Dermatological manifestations and arthralgia are the

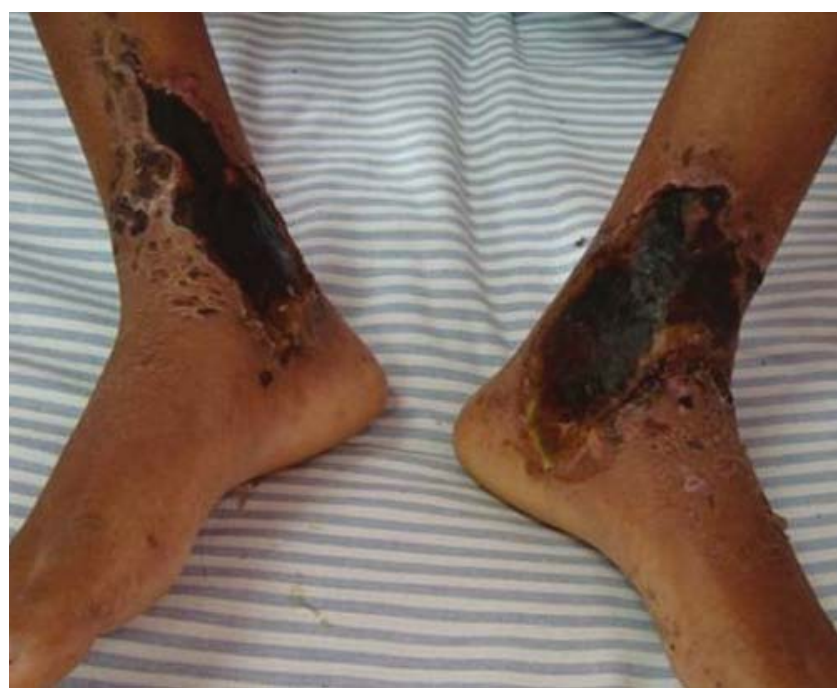

FIGURE 3: Extensive necrotic areas 
TABLE 1: Laboratory data

\begin{tabular}{lll}
\hline Laboratory data & Results & Reference value \\
\hline TSH & $0,08 \mathrm{UI} / \mathrm{ml}$ & $0,4-6,0 \mathrm{UI} / \mathrm{ml}$ \\
T4 & $2,82 \mathrm{ug} / \mathrm{dl}$ & $4,5-12,5 \mathrm{ug} / \mathrm{dl}$ \\
Anti-TPO & $674,8 \mathrm{UI} / \mathrm{ml}$ & $<40 \mathrm{UI} / \mathrm{ml}-\mathrm{Negative,} 40-100$ \\
& & $\mathrm{UI} / \mathrm{ml}-$ Borderline, $>100 \mathrm{UI} / \mathrm{ml}$ - Positive \\
Anti-thyroglobulin & $21,8 \mathrm{UI} / \mathrm{ml}$ & $<75 \mathrm{UI} / \mathrm{ml}-$ Negative, $75-100 \mathrm{UI} / \mathrm{ml}$ \\
FAN & Non reactive & Borderline, $>100 \mathrm{UI} / \mathrm{ml}-$ Positive \\
P-ANCA & $12 \mathrm{U} / \mathrm{ml}$ & Non reactive \\
C-ANCA & Negative & Positive $>5 \mathrm{U} / \mathrm{ml}$ \\
\hline
\end{tabular}

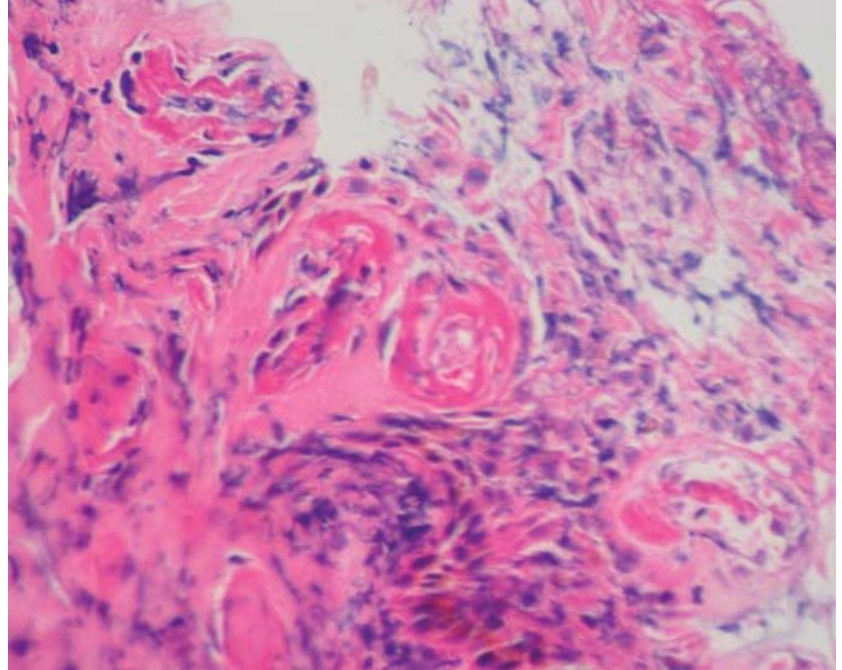

FIGURE 4: Small vessels leukocytoclastic vasculitis

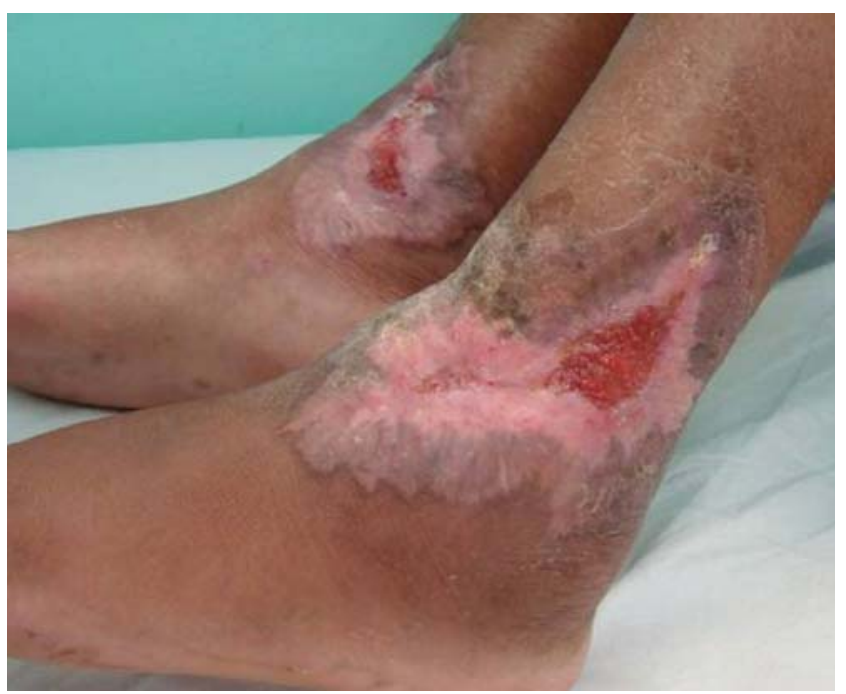

FIGURE 5: Regression of skin lesions most frequently observed findings in these cases, while lungs and renal involvement occur less frequently, usually in more serious cases. ${ }^{5,7,9}$

The pathogenesis of vasculitis associated with ATD is unknown. It was shown that PTU might bind to myeloproxidade, altering its structure and leading to the formation of auto antibodies. Another theory is that activated neutrophils produce increased amounts of myeloperoxidase, converting the drugs into free radicals and thereby generating vascular injury. It is also speculated that other factors may influence serum disease activity such as positivity for antiendothelial cells..$^{1-2,5}$

In cases where the ATD correlate ANCA-positive vasculitis, most of the literature reports concern MPO-ANCA (or p-ANCA), especially in Asian patients using PTU. ${ }^{5}$ The prevalence of MPO-ANCA in antithyroid drug users ranges from $25 \%-60 \%$ in patients treated with PTU and from 3\% - 4\% in those treated with MTM. .,5-6,8-9 $^{3}$

The first case of vasculitis associated with MTM was described in 1995 by Kawachi. ${ }^{10}$ Fever, rash, arthralgia, hepatitis and agranulocytosis are also described as side effects of this drug. ${ }^{1-4,6,9}$ In their 1999 publication Gunton et al assembled 27 cases of ATDinduced vasculitis with positive ANCA in which only one case was related to MTM. ${ }^{4}$ In our study case we observed some unique details such as p-ANCA positivity and the absence of signs of systemic disorders (only fever, arthralgia, tremor of the extremities), which lends credence to the possibility that this type of vasculitis has a clinical spectrum.

With regard to ANCA, key serological markers can be observed in cases of small vessel vasculitis. These consist of autoantibodies directed to the lysoso- 
mal enzymes of neutrophils that can be divided by indirect immunofluorescence into two main groups: cytoplasmic (c-ANCA) that reacts against proteinase 3 , and perinuclear ( $\mathrm{p}$-ANCA) that reacts against myeloperoxidase. ANCA-specific for proteinase 3 and myeloperoxidase is associated with necrotizing vasculitis, especially Wegener's granulomatosis, microscopic polyangiitis (MPA) and idiopathic crescentic glomerulonephritis. ${ }^{1,5,7}$

Vasculitis associated with MTM is a rare complication, with few cases described in the medical literature. It may in due course affect various organs such as lungs and kidneys, but few reports exist of a lethal outcome.
Early recognition of cutaneous vasculitis is crucial because drug withdrawal should be immediate in order to prevent the progression of the disease and its systemic complications. The use of steroids in extensive cases is needed to bring about a favorable outcome.

In the case described, the resolution of skin lesions after ATD was discontinued and following brief treatment with corticosteroids (in addition to the exclusion of other ethiologies, combined with the histological pattern found) strengthen the diagnosis of vasculitis associated with the use of MTM.

Few reports in the literature link the presence of ANCA and vasculitis in patients using MTM. Further studies are needed to elucidate the pathogenesis of vasculitis.

\title{
REFERENCES
}

1. Cooper DS. Antithyroid drugs. N Engl J Med. 2005;352:905-17.

2. Ahmed K, Rao S, Simha V. Antineutrophil cytoplasmic antibody-positive vasculitis in a patient with Grave's Disease: cross-reaction between propylthiouracil and methimazole. Endocr Pract. 2010;16:449-51.

3. Gumà M, Salinas I, Reverter JL, Roca J, Valls-Roc M, Juan M, et al. Frequency of antineutrophil cytoplasmic antibody in Graves' Disease patients treated with methimazole. J Clin Endocrinol Metab. 2003;88:2141-6.

4. Gunton JE, Stiel J, Caterson RJ, McElduff A. Clinical case seminar: anti-thyroid drugs and antineutrophil cytoplasmic antibody positive vasculitis. A case report and review of the literature. J Clin Endocrinol Metab. 1999;84:13-16.

5. Pietszkowski NC, Carvalho GA, Souza HN, Werka CR Jr, Borazo LA, Graf H, et al. Antineutrophil cytoplasmic antibody (Anca)-associated autoimmune disease induced by propylthiouracil. Arq Bras Endocrinol Metab. 2007;51:136-41.

6. Thong HY, Chu CY, Chiu HC. Methimazole-induced antineutrophil cytoplasmic antibody (ANCA)-associated vasculitis and lupus-like syndrome with a cutaneous feature of vesiculo-bullous systemic lupus erythematosus. Acta Derm Venereol. 2002;82:206-8

7. Brandt HRC, Arnone M, Valente NYS, Criado PR, Sotto MN. Vasculite cutânea de pequenos vasos: etiologia, patogênese, classificação e critérios diagnósticos Parte I. An Bras Dermatol. 2007;82:387-406.

8. Martin DB, Deng A, Gaspari A, Pearson F. Perinuclear Antineutrophil Cytoplasmic Antibody- Associated Vasculitis in a Patient with Graves' Disease treated with Methimazole. Skinmed. 2006;5:302-5.

9. Rodrigues R, Jorge PT. Vasculite leucocitoclástica: uma rara manifestação associada ao metimazol. Arq Bras Endocrinol Metab 2002;46:716-9.

10. Lau EY, Song SY, Chan E, Kwok J, Ma J, Kung AW. Methimazole-induced antineutrophil cytoplasmic antibody-associated diffuse alveolar haemorrhage in a Chinese woman with Graves' Disease. Hong Kong Med J. 2009;15:209-12

\author{
MAILING ADDRESS: \\ Carla de Oliveira Ribeiro, \\ Rua Presidente Backer 54/ 1601 - Icaraí - Niteroi \\ Cep 24220-041, RJ \\ Brazil \\ E-mail:carla_ribb@yahoo.com.br
}

How to cite this article: Ribeiro CO, Magrin PF, Vilar EAG, Durães SMB, Estrella RR. Cutaneous leukocytoclastic vasculitis in the presence of methimazole therapy. An Bras Dermatol. 2013;88(2):283-6. 